\title{
Great-Grandfather's Nurse
}

Alexandria, 1954

She is sitting on the terrace, holding

My small hands. Dressed in her whites,

She is the angel I have wished to touch.

Her laughter floats and falls around me

And becomes the house I want to live in.

Again, Marta, I say, again. She pulls me up

Clicking her tongue, her smooth legs

Brushing mine, and my face nestles

Into the easy scoop of her shoulder.

I smell the scent of flowers or spices.

Again, Marta, again. Upstairs

Where I do not want to go

My great-grandfather is sleeping

Through his pain and illness

And I am lucky, falling, falling

Over the landscape of Marta's legs.

My mother smiles and locks her arm

In my father's. My grandfather is winking

And whispering into my grandmother's white hair.

Krikor, he says, you little knave,

Krikor, you scoundrel, you little mouse.

And before I know what I am doing

I whisk the hem of her dress up,

Kiss her thigh and stand before her

Boyish and full of love.

Then what?

Confusion, shouting.

My great-grandfather waking,

Beating his cane against the metal bed.

Marta rising, climbing the stairs

Toward some retribution, 
The oaths streaming down.

The terrace emptying out.

The Alla aqbar of the muezzin

Calling the faithful.

The minarets, the hot sun, the white city.

My lips full of fear and prayer.

My heart full of nonsense,

Never as young, and the sea,

The blue sea in the distance,

The cold, unimplicated sea.

BeEthoven: Sonata No. I4

for Roma

You were at the piano playing the "Moonlight," A name Rellstab gave it when he heard The Adagio, and remembered moonlight Flecking the waves of Lake Lucerne.

But this was afternoon, in Boston,

The sun lighting up your apartment

Like a flare, your fingers laboring

Against a dead middle- $\mathrm{C}$, and an A

Which twanged in its several pitches.

But it was Beethoven nonetheless,

Surviving the accidents of time

And circumstance, even the unlikely name.

Outside, three floors below,

The Asian children - Vietnamese, Cambodian? -

Recently arrived like the last of so many

Witnesses, were playing among themselves,

Squealing in their small voices to the ends

Of the street. You'd said you'd seen them

In winter, the girls in sun dresses and sandals,

The boys in short-sleeved shirts, as though

Their parents knew no changes of season, 